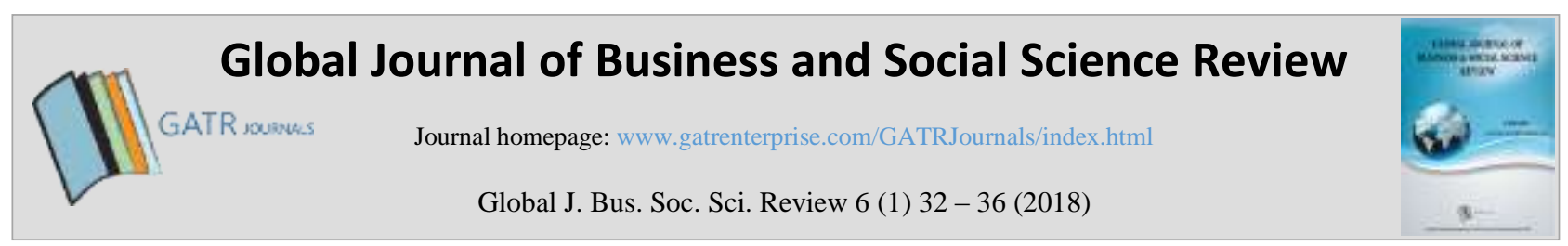

\title{
Criminal Policy on Hidden Defects in Marriage in Indonesia
}

\author{
Anny Retnowati, ${ }^{1}$ MG. Endang Suminarni ${ }^{2}$ \\ Universitas Atma Jaya Yogyakarta, Indonesia
}

\begin{abstract}
Objective - Articles 28A-28J of The Second Amendment of the 1945 Constitution provide specific and detailed arrangements for the protection of human rights. These include the protection of the right to live and the right to have a family.

Methodology/Technique - The purpose of marriage is for couples to obtain material and spiritual happiness. Many previous studies have indicated that divorce is caused by various factors related to non-fulfilment of rights and obligations between husband and wife. One of those factors is the existence of hidden defects occurring after marriage.

Findings - This study uses normative legal research based on legal facts regarding hidden defects in marriage. The research results are used to develop arguments based on legal and normative facts that may be used to inform the development of new legal policy for the solution of disputes between husband and wife caused by hidden defects in marriage.

Novelty - The research problems can be formulated as follows: (1) what is the understanding and purpose of marriage between husband and wife? and (2) how is criminal law policy in the case of hidden defects in accordance with happy and eternal marriage based on the Only God?
\end{abstract}

Type of Paper: Review.

Keywords: Service Quality; Servqual; Distance Education; Higher Learning Institutions.

JEL Classification: J12, K41, K36.

\section{Introduction and Research Problems}

The second amendment of the 1945 Indonesian Constitution contains special and detailed provision for the protection of basic human rights, contained in arts $28 \mathrm{~A}-28 \mathrm{~J}$ of chapter $\mathrm{X}-\mathrm{A}$. The basic human rights contained in those articles, among others, relate to the right to live, the right to have a family and to continue offspring, the right to education, the right to work, and the right to practice a religion. Of those rights some of these are specifically attached to human beings, such as the right to have a family and the right to continue offspring. These rights are provided in art $28 \mathrm{~B}$ which states that "everyone has the right to form family and the right to continue the offspring through legal marriage".

\footnotetext{
* Paper Info: Received: December 19, 2017

Accepted: February 09, 2018

* Corresponding author:

E-mail: annyretnowati@gmail.com

Affiliation: Universitas Atma Jaya Yogyakarta, Indonesia
} 
The right to form family and the right to continue offspring are provided in Law Number 1 of Year 1974 concerning Marriage. Article 1 of that law contains provisions relating to the understanding and purpose of marriage. Article 1 states that "marriage is the physical and spiritual bond between a man and a woman as husband and wife in order to form a happy and eternal family (household) based on the Only God". (Abdurachman, 1985. p. 64).

In some cases, the purpose of marriage cannot be achieved, and this often leads to divorce. Some situations leading to divorce include polygamy, hidden defects in marriage, and mutual termination of the marriage. In Indonesia, marriage is considered to be a sacred institution. Accordingly, marriage is regulated in both civil law and criminal law.

The regulation of marriage is important in Indonesia because families, which are the result of a marriage, have a profound effect on whether Indonesia is able to achieve its goals to become a prosperous country. Therefore, marriage must be planned in accordance with the applicable provisions.

Various supporting studies have indicated that one of the leading causes of divorce is the non-fulfillment of rights and obligations between a husband and wife. One of those factors is the existence of hidden defects after a marriage. Some examples of this include: in Wonosari Religion Court (Case Number 0230/Pdt.G/2007/PA.Wno) the marriage between the applicant and the respondent was determined to have no legal force ( http://news.detik.uin-suka.ac.id/6627 12 June 2017 at 00.25 AM). Further, in the Barsalina (20) case which occurred in Polewali Mandar, West Sulawesi, the parties marriage was cancelled after the applicant found out that her husband was in fact a woman (http://news.detik.com/berita/2914439/antara-ichadan-ichal-kisah-penipuan-cinta-sejenis-yang-berujung-penjara 21 July 2017 at 11.12 AM).

Marital problems are not only regulated by private law, but also in penal law, as provided in Law Number 23 of Year 2004 concerning Nullification of Household Violence. The prevailing laws and regulations give legal certainty to the purpose of marriage, which is to provide eternal happiness.

In fact, the prevailing legal policy still presents new problems which do not guarantee the purpose of marriage, such as where there are hidden defects which are only identified following marriage. Suggestions for reform to legal policy is therefore needed to facilitate the settlement of these disputes between husband and wife, in order to protect the purpose of marriage. Based on the above background, the two research problems are as follows:

(a) What is the understanding and purpose of marriage between a husband and wife?

(b) How does criminal law policy deal with cases of hidden defects in marriage based on the "Only God" purpose of marriage?

\section{Methods}

This study is normative legal research based on legal facts concerning hidden defects in marriage. The data analysis uses a qualitative model which analyzes data based on data which is systematically obtained from interview results and library research.

\section{Underlying Theories}

An understanding of criminal law policy can be seen from legal and criminal politics. According to Sudarto, political law is the policy of a state, established by competent bodies, to establish rules and regulations that aim to achieve the goals of a society.

Based on this understanding, Sudarto further states that carrying out "criminal law politics" means holding elections to achieve the best results of criminal legislation and meeting the requirements of justice and efficiency (http://www.definisi-pengertian. com/2015/05/pengertian-ruang-lingkup-kebijakan-hukum.html28 January 2017 at $06.34 \mathrm{AM}$ ). 
According to Sudikno Mertokusumo, "law serves as protection to human interests". In order to protect human interest, the law has to be fulfilled. Fulfillment of law can run normally, but can also occur as the result of a violation of another law. Therefore, a person in violation of prevailing marriage laws will be liable to sanction.

\section{Results and Findings}

\subsection{The Purpose of Marriage}

The requirements of marriage are as follows:

1. Both parties must consent to being bride and bridegroom (art 6(1) of Law Number 1 of Year 1974 concerning Marriage). Parents or guardians and close relatives must not force the parties to carry out the marriage if they do not agree.

2. The groom must be at least 19 years old, and the bride must be at least 16 years old (art 7(1) of Law Number 1 of Year 1974 concerning Marriage).

3. Both the bride and groom must not have any familial relationship with the other (art 9 of Law Number 1 of Year 1974 concerning Marriage), except for cases of polygamy which are permitted by art 3 L(1 $\})$ and art 4 of Law Number 1 of Year 1974 concerning Marriage.

4. The parents of the bride and groom, for those who are not yet 21 years old, must consent to the marriage, as long as the laws of their religions or faiths are not contrary to the marriage.

Marriage, according to Sajuti Thalib, is a holy, wide and strong agreement in order providing for the legal union between a man and a woman to form an eternal, well mannered, loving, peaceful and happy family (Mohamad Idris,1995, p.2). Further, Imam Syafi'i defines marriage as a contract which legalizes sexual intercourse between a man and a woman (Hosen,1971, p.65). According to Hazairin, the core of a marriage is sexual intercourse. To him, there is no marriage if there is no sexual intercourse (Hazarin,1961, p.61) Scholten defines marriage as a legal relationship between a man and a woman, to live together eternally and to be recognized as a legal couple by the state (Scholten,1982, p. 31). However, according to Wantjik Saleh, marriage is a physical and spiritual bond between a man a woman as husband and wife (K. Wantjik,1982).

\subsection{Criminal Law Policy}

Criminal law policy can be viewed in terms of legal policy and criminal policy. According to Sudarto legal policy refers to efforts by government to establish effective regulations in accordance with the conditions of society at a certain time. Based on this, Sudarto further states that to carry out "criminal law policy" means to make choices to achieve the best criminal law statutes which fulfil the requirement of justice and utility. (http://WWW.definisi-pengertian.com/2015 /pengertian - ruang-lingkup-kebijakanhukum.html 28 January 2017). Applying criminal law policy in marriage is important because marriage is considered a holy institution. However, divorce is a very real concern, and is becoming more common in modern society. One of the leading causes of divorce is in fact hidden defects in marriage.

An example of hidden defects in marriage can be seen in the case of Barsalina (20), described above. This case was brought based on art 378 of the Penal Code which states that: "the one who intentionally benefits himself/herself or the other person unlawfully, by using false name or status, by using tricks or series of lies moves another person to deliver a good to him/her, or to give debt or to wipe out credit, is threatened because of deception with 4 (four) years imprisonment at the longest".

Further, in Case Number 0230/Pdt.G/2007/PA.Wno, the marriage between the applicant and respondent was found to be invalid as a result of the wife's previous marriage which was found to still be current . This case was brought based on art 279 of The Penal Code which states that "the one who carries out marriage although he/she knows that the former marriage or marriages can be legal obstacles for that marriage" and 
"the one who carries out marriage although he/she knows that the marriage or marriages with the other parties become obstacles for that marriage". Further, "if the one who performs the act based on paragraph (1) point a hides toward the other party that the former marriage becomes the legal obstacle for that marriage, he/she can be threatened with 7 years imprisonment at the longest".

From a civil law perspective, hidden defects are provided in arts 1504 to 1512 of the Civil Code. Article 1504 of the Civil Code provides that the seller is always held to be responsible for the existence of hidden defects. Hence, if a buyer recognizes that there is a hidden defect in the goods they are selling, they have two options for rectifying those issues, which are contained within art 1507 of the Civil Code.

1. Refunding the goods upon return by the purchaser; or

2. Providing compensation for the defect, where the purchaser wishes to keep the goods as sold.

Hidden defects are a common occurrence, and they have the potential to cause great conflict in marriage. However, parties are able to settle these types of disputes in the Religion Court, the likely result of which is cancellation of marriage or divorce. To that end, most people in Indonesia are not aware that these issues may also be resolved through recourse to criminal law. Marriage is one of the basic human rights, therefore, if there is hidden defect in a marriage which is the result of an unlawful act, aggrieved persons are able to commence an action under either civil or criminal law. This is because the law serves as protection of the human interest.

\section{Conclusions, Implications and Significance}

The right to form family and continue offspring has been regulated in Law Number 1 of Year 1974 regarding Marriage which contains provisions relating to the purpose of marriage. For example, art 1 states that "marriage is the physical and spiritual bond between a man and a woman as husband and wife, in order to form a happy and eternal family (household) based on the Only God". The criminal law policy against hidden defect in accordance with the purpose marriage based on the "Only God" has been amended to supplement the provisions of art 378 of the Criminal Code. This aims to encourage, promote and protect the purpose of marriage in Indonesia.

\section{Recommendations}

Based on the above conclusions, to achieve a prosperous marriage absent of any hidden flaws, the following two recommendations are made:

1. There should be renewed focus on educating society on the available avenues for seeking recourse where there is a defect in their marriage, through both civil and criminal laws.

2. The content of art 378 of The Penal Code should be revised and supplemented as follows: "the one who purposely benefits himself/herself or the other person unlawfully, by using false name or status, by using tricks or series of lies moves another person to deliver a good to him/her, or to give debt or to wipe out credit, and deceit in marriage is threatened because of deception with 4 (four) years imprisonment at the longest".

\section{References}

Abdurachman, 1985. The Set of Regulations, Jakarta, Akademika Pressindo.

Retnowati, A. (2016). The Investigation Model of Malpractices in Hospital Based on Principle of Justice and Legal Protection Through Due Process Model Approach in Indonesia. Procedia-Social and Behavioral Sciences, 219, 627631.

Hosen Ibrahim, 1971. Comparison of Marriage, Divorce and Reconciliation Problems, (comparison in the matter of

Global J. Bus. Soc. Sci. Review 6 (1) 32 - 36 (2018) 
marriage, divorce and reconciliation) Jakarta, IhyaUlumudin.

Hazairin, 1961. Indonesian Family Law, Tintamas.

Idris, R. M. (1996). Islamic marriage law: an Analysis of Law No. 1/1974 and Compilation of Islamic Law. Scholten, quoted by Prawiro Hamidjojo and Safioedin, 1982.

Sianturi, S. R. (1983). Criminal Acts in the Criminal Code The following description. Alumni AHM-PTHM. Soesilo, R. (1991). KUHP serta komentar-komentarnya. Poutela, Bogor.

Saleh, K. W. (1987). Indonesian Marriage Law. Ghalia Indonesia.

Website

(http://WWW.definisi-pengertian.com/2015/pengertian-ruang-lingkup-kebijakan-hukum.html 28 januari 2017

http://news.detik.uin-suka.ac.id/6627 12 juni 2017 at $00.25 \mathrm{AM}$

http://news.detik.com/berita/2914439/antara-icha-dan-ichal-kisah-penipuan-cinta-sejenis-yang-berujung-penjara 21 juli 2017 at $11.12 \mathrm{AM}$ 